Analysis of management narrative to understand social marketing strategy: The...

David Russell; Gillian Sullivan Mort; Margee Hume

Australasian Marketing Journal; Nov 2009; 17, 4; ABI/INFORM Global pg. 232

\title{
Analysis of management narrative to understand social marketing strategy: The case of 'Branding Logan City'
}

\author{
David Russell ${ }^{a}$, Gillian Sullivan Mort ${ }^{b, *}$, Margee Hume ${ }^{a}$ \\ a Department of Marketing, Griffith Business School, Griffith University, Kessels Rd, Nathan, Old 4111, Australio \\ 'School of Management, Faculty of Law and Management, La Trobe University, Melboume Vic. 3086. Australia
}

\section{A R T I C L E I N F O}

\section{Keywords:}

Social marketing

City branding

Local government

Positive self image

Social capital and economic development

\begin{abstract}
A B S T R A T
This paper presents a unique city branding case applying narrative analysis to the marketing manager's account of his long running campaign to brand Logan City. The analysis finds that the campaign has many of the hallmarks of social marketing, but focuses strongly on citizen's positive self image and social capital development. Elements of city branding are employed but the approach is 'self directed', rather than the usual approach of 'other directed'. The desired outcomes are a positive self and community image laying the foundation for a community confident to undertake various economic development tasks. Implications. for social marketing theory and management and future research are discussed.

Crown Copyright 2009 Published by Elsevier Ltd. on behalf of the Australian and New Zeland Marketing Academy.
\end{abstract}

\section{Introduction and approach}

lncreasingly narrative and narrative analysis has been applied in many areas of enquiry (Czarniawska, 2004; Gabriel, 2000: Rhodes and Brown, 2005). Narrative "is a form of meaning making. . [which] recognises the meaningfulness of individual experiences" (Polkinghorne, 1988). Some assert that a narrative stance allows a more meaningful, practitioner relevant exploration of strategic issues (Wilson, 1979). Researchers in marketing have underlined the "messy nature" of meaning and called for new intellectual developments to theorize and specify the "meaning below the surface" (Mick et al., 2004). The application of narrative analysis is still emerging in marketing in general but recently Sitz (2008) has adopted discourse analysis to understand consumer experience. Narrative analysis is considered a type of discourse analysis (Søderberg, 2006). A narrative view of strategy stresses how language is used to construct meaning (Barry and Elmes, 1997). It explores ways in which organisational stakeholders create a discourse of direction about becoming, being or having been. While conceptual, qualitative and quantitative papers have been introduced in the study of social marketing (Bloom and Novelli, 1981: Hill, 2001), narrative analysis of manager's strategising is much less common. The use of narrative analysis has potentially much to offer in developing further understanding of marketing and specifically social marketing strategy development. The overall question driving this paper then is How can analysis of management narrative shed light on strategies for social marketing?

\footnotetext{
- Corresponding author. Tel.: +61 39479 1318; fax: +61 394795971 .

E-mail address: g.sullivan-mort@latrobe.edu.au (G.S. Mort).
}

Consistent with the focus of this paper, an in-depth case study approach was followed (Yin. 1994). We use a single case study of the instrumental type (Stake, 2000). We have selected the 'Branding Logan City' case as an appropriate context in which to investigate the research questions for a number of reasons. Logan City Council is a large nonprofit organisation operating at the regional level with a defined history, diverse stakeholders, numerous challenges and substantial involvement with the whole community. The size and sustained existence of the organisation reflects its ability to engage in exchanges and deploy resources in the achievement of its goals. Following Stake's (2000) recommendations for the study of the particular case we include a description of the following; the nature of the case in a brief case overview including physical setting and the key informant through whom the case can be known. The key informant was the marketing and communication manager for the council for a number of years and was responsible for the development of the Logan branding strategy embedded within a strategic social marketing framework. The narrative is the record of the keynote address given by the informant at the 2007 International Nonprofit and Social Marketing (INSM) Conference, Brisbane (Russell, 2007). As such it is part of the public record and comprises secondary data generally available for usage and analysis. Consistent with the approach in previous instrumental case studies (Sullivan Mort et al., 2007) the narrator speaks directly to the reader as an author of this paper.

The paper proceeds as follows. First a case overview is presented followed by the complete narrative of the address to the 2007 INSM Conference. The paper then presents an analysis of themes within the narrative enfolding social marketing and other theoretical perspectives consistent with Eisenhardt (1989). The paper concludes with a discussion and implications. 


\section{Manager's brief case overview}

The 175,000 residents of Logan City in South-East Queensland, Australia, comprise a community like many others. They enjoy considerable opportunity in lifestyles, education and employment. Many are wealthy but many more are poor. Ethnicity is diverse with 160 cultures represented. Youth holds primacy with $53 \%$ aged 35 or younger. Other than geography and a certain degree of daily shared experience there was little to bind this community into a cohesive entity.

The belief that enhanced civic pride could help engender better quality of life drove the implementation of an eight-year city image campaign by the local authority that has explored many facets of social marketing and kindred disciplines. The lessons are not prescriptive. There is, however, a hope that social marketing can be defined more broadly to encompass attitudinal change rather than just behavioural change and that city branding or place marketing can be more inclusive as a means of building greater social cohesion.

\section{Manager's narrative}

In 1999. Logan City in South-East Queensland was just twenty years old and bore many similarities to a gawky adolescent as it sat sandwiched between its much older and more sophisticated neighbours: Brisbane and the Gold Coast. Logan was the bastard child of anonymous government line-drawers who in 1979 adjusted boundaries on electoral maps to create a new city that had no compelling reason to exist other than alleviating growth pressures in neighbouring entities. This much became apparent after I had been appointed Marketing Manager of Logan City Council on the eve of the Millennium and began to catalogue the city's unique selling propositions. It was a frighteningly short list.

Logan had no casino, no convention centre, no cathedral, no palm-fringed beaches, no rainforest, no skyscrapers. The dearth of attractions is perhaps no more telling than in Logan's absence of even a Central Business District (CBD). If this is not a unique characteristic it is most assuredly a very rare one and it compounds the place branding challenge. Indeed, Logan had no tourist attractions of any note. In fact, Logan's tourism infrastructure amounted to just three motels. For a city of 175,000 people at the very heart of one of the major tourist regions in the southern hemisphere that indicated a marketing challenge far more difficult than I had envisaged when drafting my job application. How to sell this place became a mantra that bedevilled my days. Ultimately the conclusion cannot be escaped that if you strip away all of the natural and constructed artefacts of a city, the only ingredient you have left is the people. Thus, given the paucity of alternatives, the marketing challenge became: how to sell the people of Logan to the world?

A realisation dawned that we could not sell Logan to anyone outside if those who lived in the city were not ambassadors themselves: the dissonance would have been deafening. Logan at that time was generally regarded as a socio-economic basket-case. There are no baseline studies to support that contention but contemporary media coverage was almost universally negative and bordering on derisory. Logan was like the bad neighbour defiling the image of an otherwise well-kept precinct. It is a reasonable contention, supported by anecdotal comment from locals, that a great many of Logan's residents felt uncomfortable about the city's image and reputation.

In these circumstances the marketing objective became internally focused: how to give these people reasons to have pride in themselves? Until they believed in themselves and felt comfortable 'talking-up' where they lived, there would be little point expending funds extolling Logan's supposed virtues to external audiences. So... how to turn a sow's ear into a silk purse?
When the place marketing efforts of other cities are examined they reveal a plethora of slick, sophisticated imagery and taglines used to tempt target audiences into visiting the destination, investing there or even choosing to start a new life within its boundaries. The uncommon circumstances of the Logan challenge dictated a different approach. 1 believed attitudinal change would only come gradually and that this city image campaign would necessarily have to be a reasonably lengthy journey in contrast to the short-term nature of many marketing programs. A foundation stone was the belief that success would only be achieved incrementally and that the campaign would get ahead of public sentiment at its own peril.

There was a clear imperative to delineate the positives of living in Logan - but in a somewhat muted way because the place itself is not slick. Accordingly, instead of professional photography, I commissioned a disparate group of amateurs to capture images they felt represented life in Logan. Many of the submissions, not surprisingly, were ill-suited to promotional purposes. But enough were. These were provided to an advertising agency which bolstered their inherent attractiveness by graphic design and art execution.

There remained the issue of how to give a theme to this nascent clarion call for pride. With so few distinguishing features, there was really only one left almost by default. It was Logan's ethnicity. That was paraphrased as 'diversity' and was given some marketing zest by the use of a positive and emotive noun. The inaugural campaign theme became "Logan: A celebration of diversity". The ad agency insisted we have a call to action and, thus, our advertising was emblazoned with "Discover our diversity".

But what to do with the concepts that had been developed? The images were bright and alive, as was the graphic design. It would have been wonderful to have had glossy magazines to showcase them pleasantly but local papers were essentially just black and white vehicles. The glossies were too expensive and scarcely targeted our audiences anyway. Then came the realisation that outdoor advertising - billboards - could meet my marketing constraints. Billboards enabled good use of colour: they could remain in place for several weeks, thus reinforcing reach and frequency; and they could be arrayed so as to talk, primarily, to people who lived within Logan and - to ensure value for money those who drove through or past the city's periphery. The billboards were duly booked and the campaign began in earnest.

The marketing team awaited the plaudits but grew mystified as silence enshrouded us. Oh, there were quite a few nice comments from colleagues at Council but. generally, the whole exercise was greeted as if with a yawn. My heart sank and I pondered ever more despondently what had gone wrong. I was yet to discover the only true Key Performance Indicator (KPI) when expending public funds. It would come later and be all the more startling for how blindingly obvious it was. Still, the Logan city image campaign was born and a rare decade-long adventure began.

There was one inherent stylistic of the campaign that has remained fairly much intact throughout. It was brevity and simplicity. Billboards are 'consumed' by the public usually at high speed and in competition with a thousand and one other distractions such as maniacal drivers trying to kill you by their incompetency; the inanities of radio personalities or the intrusive chirrup of mobile phones. If, as a marketer, your billboards are wordy or complex then you have wasted your money and your creative ability. Keep it simple, stupid was a dictum never more apt than in grounding the users of outdoor advertising. Sadly, it is more often than not honoured in the breach. Such advertising - and there is lots of it (look around you) - becomes an exercise in futility. Nor was the Logan city image campaign to always escape its clutches but these were lessons still to be learned.

While the first iteration of the Logan campaign generally drew a low-key response, some individuals were very pleased with the effort. Multicultural Affairs Queensland, the state government's 
agency for cultural diversity, extolled the virtues of the campaign and utilised quite a few of the images in its own publications. But otherwise, little was said. Indeed, some of the most negative response came from Council's ad agency itself. The principal twice pleaded that we not use an image of a young man with multiple ear and lip piercings. He said the image was confronting and not suitable. My response was that $53 \%$ of Logan's population was aged 35 and younger and that the youth in question was just like so many others across the city. How could the campaign ever hope to talk directly to target audiences if it used only sanitised imagery that was not reflective of reality?

The following year - 2000 - my staff and I were eager to push our ideas further. We felt the silence which had greeted the first iteration of the image campaign perhaps meant that ethnic diversity was not universally embraced and so we expanded our message to a more generic theme that would, hopefully, appeal to as wide an audience as possible. Our chosen theme was 'Loving life in Logan'.

The hallmarks of this iteration were a continuation of our original characteristics: simplicity of message to correspond with the constraints of billboard advertising: bright colours: and imagery which reflects a diversity of people and lifestyles. This time, however, we added a new element which has remained subsequently: a dash of quirky humour contained in the photography. Heather Scott, Council's graphic designer and a driving force for the whole campaign, began directing the artwork and staged the many photo shoots with photographer. Les Dixon. The subtlety of much of this imagery would not be readily appreciated in a billboard context but it worked well in newspaper reproduction and other brochures and pamphlets we used as supporting materials.
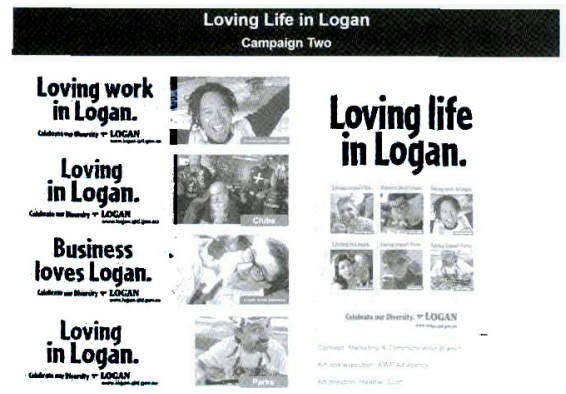

Again, there was a small element of controversy: the use of three bikers who - prima facie - were a trifle daunting in appearance. However, close examination reveals their club colours are those of the Vietnam Veterans which is socially acceptable compared with outlaw bikers. Additionally, the central personality who looks 'tough' was actually a Baptist Minister and still regularly attends church every Sunday. You can not judge a book by its cover! Another zany quirk of this phase of the campaign was a young man with gelled, hair, loud shirt, beads and other hippy accoutrements. He was actually a Mormon missionary who willingly swapped his white shirt and black pants at our request when another person failed to show for the photo shoot.

The next iteration of the campaign (Three) was a diversion. It was also a failure in many ways.

Its genesis came in political pressure from Councillors (elected community representatives) who had enjoyed the first two phases of the city image campaign and who thought that funds raised through rates (de facto property taxes for which Councillors copped a lot of flack) should sensibly be invested to make Councillors look good. The timing of this iteration came on the eve of triennial Council elections and it had a theme which pleased the paymasters: 'Count on your Council'. It is open to construction that one way of continuing substantial Council funding for the campaign was to deliver a dividend to Councillors. Make the community feel happy about Council and sitting Councillors will get re-elected. Nice notion. As it happened, all ten Councillors got re-elected - a major rarity anywhere.
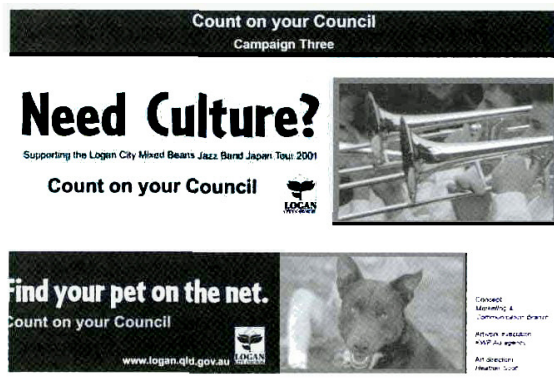

There is no suggestion that this campaign created or stimulated a climate in which Councillors were seen to be a benefit to the community. The unanimous re-election of all Councillors was, however, an interesting aberration. Even so, subsequent research indicated that people did not like an advertising campaign which told them that Council was 'good'. They did not mind being told they (the community) were good but they drew the line at their own money being spent to tell them Council was doing a good job. This is the essence of democracy: people can sniff out something dodgy even if they can not put their finger on just what it is. So, we learned to keep the focus on the community. It was an interesting diversion and an educative one.

Emboldened by the apparent success of things so far (the lowkey negative response to Campaign Three notwithstanding) I decided to tell the community what I really wanted them to feel. The message was blunt if albeit somewhat complex: Proud to be me. Proud of my community. It was now four years into this odyssey and I was becoming impatient to achieve measurable success, losing sight in that seduction of ego that others alone will be the arbiters of such issues. Like feisty consumers everywhere they decided they would make up their own minds.
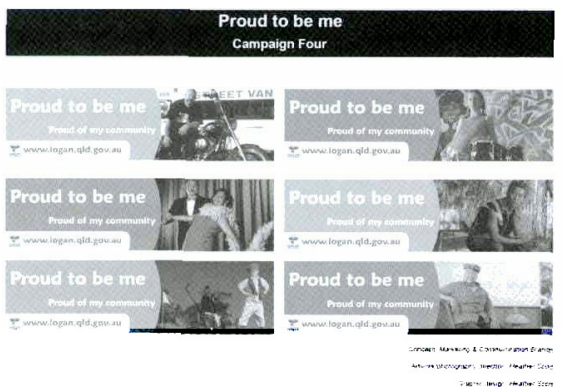

There were several mistakes in this campaign. We made the images way too complex. There were subtle political messages 
encapsulated in most of the images (such as a brown-skinned woman mechanic in overalls clutching a giant wrench). Others were so complex their intrinsic meaning can still be the subject of debate. Frankly, we got too clever for ourselves. There was no public animosity or complaint about the campaign but subsequent research showed they certainly did not take to it, either.

Each time we finalised a phase of the campaign we had about six months to mull-over the lessons and re-energise ourselves for the next initiative. We had by now learned quite a few parameters and Campaign Five became one of our most successful. The theme was contributed by team member, Paula Weston, and its simplicity was wonderful: 'Find your place in Logan'. The core theme was bolstered by various taglines for different images such as: 'Join a team': 'A place for opportunity' and even 'A place to worship'. Bright, vibrant colours were again a mainstay.

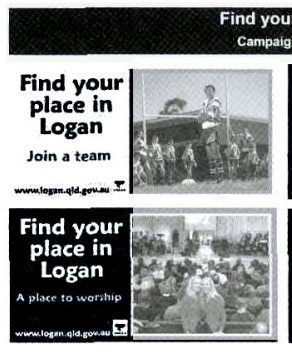

d your place

ampaign Five

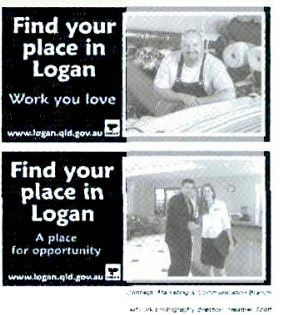

We knew this phase was a success because of the deafening silence which greeted it. Are you mad, you ask? No. Market research confirmed our intuitive understanding thanks to some learnings from previous years. We had found that when a campaign did not gell with the community, they would express their annoyance. Sometimes it would be letters to the editors of local papers but mostly passing comment to their elected representatives. As a bureaucrat you learn very quickly that Councillors do not like being told that ratepayers' funds are being wasted on frivolous exercises. That sort of niggling negativity that can cost a Councillor their seat at the next elections. So, when an initiative like this is shrouded by silence, you give thanks for you know that the people find your efforts acceptable. It's an unusual barometer but a bloody effective one.

Campaign Six was another success and reprised our most popular theme: 'Loving life in Logan'. Our photographic imagery was still quirky but not complex.

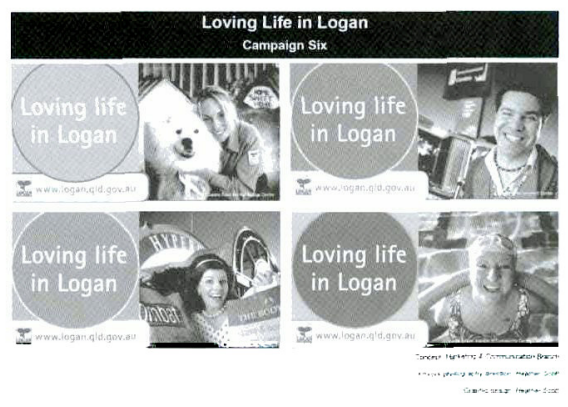

The billboards depicted happy individuals indulging their recreational pursuits. We were not preaching at anyone that they should like Logan and we ignored any call to action. We just wanted to convey the impression that if you lived in Logan, life was good. The people liked it!

By this time, 2006, our research had told us that people liked seeing images of the facilities and features of the city so we did just that.

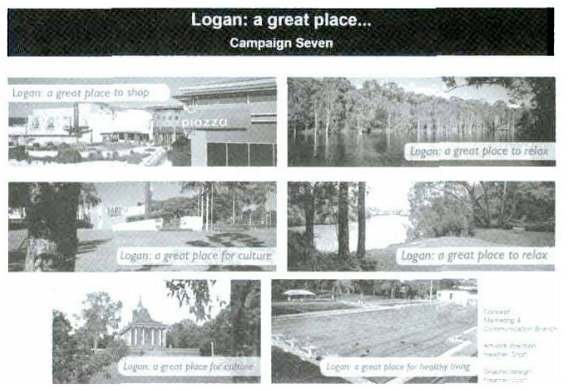

A notable departure from previous practice was the absence of featured individuals in the imagery. The focus was wholly on the attraction. The overall theme was: 'Logan: a great place'. Specific taglines were: 'A great place to shop'; 'A great place to relax'; 'A a great place for culture'.

The final iteration of the campaign was quite different for several reasons. Councillors, mindful of another encroaching election, demanded an economic development thrust be incorporated into the promotional effort. This was actually facilitated very nicely by the opening of IKEA's largest store in the southern hemisphere in Logan. It was joined by another $\$ 150$ million adjacent store and complemented the nearby Logan Hyperdome, one of the largest shopping malls in the nation. Pertinent is the fact that retailing is the largest employment and economic development sector in Logan. The marketing team had also acquired a new member, graphic designer Michelle Atkinson, who combined with stalwart Heather Scott to produce some very high quality outdoor advertising. The theme was: 'Love it? Get it in Logan'.

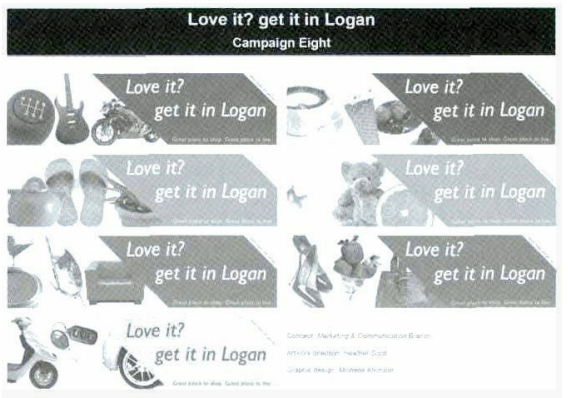

The most notable departure in this phase of the campaign was that, for the first time, we were really talking to external audiences. 
The campaign still addressed our core strategic imperative: to make Logan people feel good about where they lived. But this time we could potentially demonstrate a financial return on the investment while bolstering Logan's image and reputation beyond the city boundaries.

\section{Analysis and discussion of narrative}

Since Wiebe $(1951,1952)$ identified that it was possible to consider selling brotherhood like soap the sub-discipline of social marketing defined as (Kotler and Zaltman, 1971) "the design. implementation and control of programs calculated to influence the acceptability of social ideas and involving considerations of product planning, pricing, communication distribution and marketing research" has grown in its application base. While there is a diverse range of other applications, many campaigns focus on health and health promotion (Hill, 2001). Indeed the UK government has recently founded all health initiatives within a social marketing paradigm (UK Department of Health, 2004). In contrast to the growing application to physical health in particular (Grier and Bryant, 2005), the "Logan City Branding" campaign was undertaken with the intention of promoting a positive idea of the City of Logan, of changing attitudes and community perceptions of the place residents live in and share with each other. The target was positive community self perception - perhaps even brotherhood. Civic pride was certainly involved, consistent with Wood (2006). In this the target is more reminiscent of earlier campaigns and more consistent with earlier conceptualizations of social marketing (Kotler and Zaltman, 1971; Wiebe, 1952) as related to ideas and social issues than later approaches and campaigns that focus on behaviour change at the individual level (Andreasen, 1995), though it is still recognisably located within a broad social marketing approach.

Located within social marketing the campaign also draws on influences from research streams such as economic and social impact of events (Wood, 2005) and other approaches to understanding and enhancing local community development (Cameron and Gibson, 2005: Jordan, 2001) that take a more critical and poststructuralist approach to understanding community and development. This may reflect the particular context or type of organisation, a local council, which undertook the campaign as well as the individual manager's strategising. Increasingly, councils are not solely concerned with 'the three Rs - rates, roads and rubbish'. They are also concerned with community. well being and economic development following changes in practice (Nalbandian, 1999) and important theoretical advances linking social capital and economic advancement (Woolcock, 1998).

The campaign also uses many of the approaches and images of destination branding and place marketing (Morgan et al., 2002). It adopts a re-imaging approach rather than simply extolling the virtues of the city, an approach based on a pragmatic analysis revealing few if any natural or constructed attributes upon which to develop a traditional image campaign. While it has been noted (Bennett and Koudelova, 2001; Smith, 2005) that imaging has a long history, in recent years local government has been argued to have initiated more extensive, and yet more subtle, attempts to manipulate city images. Hubbard identifies that increasing budgets are being set aside for image construction and advertising, not only about existing assets but to re-image or reinvent a place (1996). Researchers have approached this phenomenon in a variety of ways including as a form of communication (Burgess and Wood, 1988), as a type of urban governance (Stoker and Mossberger, 1994) and as a mode of marketing (Fretter, 1993). Within this campaign's social marketing approach, in the campaign the traditional approaches to place marketing and re-imaging that are 'other directed' are subverted by making them 'self directed'. Others are not told about Logan's attributes until the last stage of the cam- paign. Similarly, rather than the familiar images of beautiful natural endowment or man made wonders (for example the trade marked Queensland - Beautiful One Day - Perfect the Next Campaign of the Queensland Travel and Tourism Corporation, WIPO, 2008) the campaign focused on using images of local people and was directed at local people using amateur photography not slick studio images, further distancing itself from traditional campaigns. Schroeder (2007) has noted that this naturalistic style of photograph works to make advertising and brands more real, more authentic and thus more effective. Locating the re-imaging within the social marketing sub-discipline, as in the Branding Logan City case, is a novel approach.

Social marketing experts (Andreasen, 1995; Hastings, 2007; Kotler et al., 2002) all emphasise the need to for social marketing campaigns to be well integrated, coherent and undertaken over a substantial period of time to be successful in their objectives. Others (Walsh et al., 1993) speak of the need for persistence and a long time frame. The Branding Logan City campaign adheres to these injunctions with the manager's narrative emphasising the inter-related nature of each flight of the campaign and the campaign itself taking place over a period of several years. Though the narrative refers to successes and failures of different phases how these were measured is not entirely clear, though there was evidently a lot of self criticism and reflection on the part of the manager and the team as reflected in the narrative. For many social marketers the lack of a specific behavioural focus may constitute a problem. It is also true that the images used in the campaign moved from merely images of identity to images of action - showing for example diverse activities being engaged in as part of embracing life in Logan. (phases five and six of campaign). The arc of the campaign saw the final stages return to more familiar destination marketing themes using 'place' image without people for the first time in phase seven and finally at the end emphasising economic activities in phase eight - Get it in Logan phase of the campaign.

\section{Conclusions and implications}

The narrative of the Branding Logan City campaign provides a unique opportunity to gain insight into the strategic approach of a manager undertaking an innovative social marketing campaign aimed at the non-traditional target of enhancing people's image of their own city, and the possibilities inherent in embracing and committing to their own community. Undertaken by a local city council, the campaign used a novel combination of place branding, re-imaging, social capital enhancement and community development linked to economic development. Though social marketing was the identified approach it did not adopt the more recent preoccupations of campaigns directed to individual behaviour change. very often for a health purpose. Through adaptation of place and re-imaging campaigns, more often associated with place and tourism marketing and the use of authentic photographic images the campaign provides new insight into the application of social marketing to important though neglected fields of social change - the social change needed for a distressed locality to become revitalised and to move forward confidently to build a productive and caring community. Future social marketing campaigns can draw on some of the novel ideas pioneered here. Social marketing practitioners can draw encouragement and inspiration from a practical yet courageous application of the sub-discipline.

\section{References}

Andreasen, A.R., 1995. Marketing Social Change: Changing Behavior to Promote Health, Social Development, and the Envitonment. Jossey-Bass, San Francisco.

Barry. D. Elmes, M. 1997. Strategy retold: toward a narrative view of strategic discourse. Academy of Management Review 22 (2). 429-452. 
Bennett. R. Koudelova. R., 2001. Image selection and the marketing of downtown areas in London and New York. International journal of Public Sector Management 14 (3), 205-220.

Bloom, P.N., Novelli, W.D. 1981. Probiems and challenges in social marketing. Journal of Marketing 45 (2), 79-88.

Burgess, J., Wood, P., 1988. Decoding Docklands: Place Advertising and the Small Firm. In: Eyles, J., Smith, D.M. [Eds.). Qualitative Methods in Human Geography. Polity Press, Cambridge, pp. 94-117.

Cameron. J. Gibson, K.. 2005. Alternative pathways to community and economic development: the Latrobe Valley community partnering project. Geographical Research 43 (3), 274-285.

Czarniawska, B., 2004. Narratives in Social Science Research. Sage, London.

Eisenhardt, K., 1989. Building theories from case study research. Academy of Management Review 14, 532-550.

Fretter, A. 1993. Place marketing: a local authority perspective. In: Kearns, G., Philo. C. (Eds.). Selling Places: The City as Cultural Capital, Past and Present. Pergamon, oxford, pp. 163-174.

Gabriel, Y., 2000. Storytelling in Organizations, Facts, Fictions, and Fantasies. Oxford University Press, Oxford.

Grier, S., Bryant, C.A. 2005. Social marketing in public health. Annual Review of Public Health 26 (Annual Review). 319-339.

Hastings, G., 2007. Social Marketing: Why Should the Devil have all the Best Tunes? Butterworth-Heinemann, Oxford.

Hill, R., 2001. The marketing concept and health promotion: a survey and analysis of recent 'Health Promotion' literature. Social Marketing Quarterly 7 (1). $29-53$.

Hubbard, P., 1996. Urban design and city regeneration: social representations of entrepreneurial landscapes. Urban Studies 33 (8), 1441-1461.

Jordan. J., 2001. Community and Economic Development: Towns Shaping Their Destiny ACCORD Paper No. 4. <http://www.accord.org au/publications/ ACCORD_MalenyPaper_4.pd!> (accessed 13.05.08.)

Kotler, P., Zaltman, G., 1971. Social marketing: an approach to planned social change. Journal of Marketing 35 (3), 3-12.

Kotler, P., Roberto, N., Lee, N.. 2002. Social Marketing: Improving the Quality of Life Sage. Thousand Oaks.

Mick, D.C.. Burroughts, J.E., Hetzel, P., Brannen, M.Y., 2004. Pursuing the meaning of meaning in the commercial world: an international review of marketing and corsumer research founded on semiotics. Semiotica $152(1 / 4), 1-74$.

Morgan. N.. Pritchard. A., Pride, R., 2002. Destination Branding: Creating the Unique Destination Proposition. Butterworth-Heienemann, Oxford.

Nalbandian, J., 1999. Facilitating community, enabling democracy: new roles for local government managers. Public Administration Review 59 (3), 187-197.

UK Department of Health, 2004. Choosing Health: Making Healthy Choices Easier cmd.6374 2004. <http:/Www.dh.gov.ukjen/Publicationsandstatistics/ Publications/PublicationsPolicyAndGuidance/DH_4094550) 15.05.08.).
Polkinghome, D.E., 1988. Nartative Knowing and the Human Sciences. State University of New York Press, Albany.

Rhodes, C. Brown, A.D., 2005. Nartative, organizations and research, International Jourtral of Management Reviews 7 (3), 167-188.

Russell, D., 2007. Keynote Address 2007 INSM: Social entrepreneurship, social change and sustainability, Griffith University. Southbank. Brisbane, September. Personal communication.

Schroeder. J.E., 2007. Images in brand culture. In: Phillips, B.|, McQuarrie, E. (Eds.), Go Figure: New Directions in Advertising Rhetoric. M.E. Sharpe Inc., Amonk, NY.

Sitz. L. 2008. Beyond semiotics and hermeneutics: discourse analysis as a way to interpret consumer's discourses and experiences. Qualitative Market Research 11 (2), 177-191.

Smith, A, 2005. Conceptualizing city image change: the 're-imaging' of Barcelona. Tourism Geographies 7 (4), 398-423.

Soderberg, A.-M., 2006. Narrative interviewing and nartative analysis in a study of a cross-border merger. Management internationa! Review 46 (4), 397416.

Stake. R.E., 2000. Case studies. In: Denzin, N.K. Lincoln, Y.S. (Eds). Handbook of Qualitative Research, second ed. Sage. Thousand Oaks, pp, 435-454.

Sroker, G. Mossberger, K. 1994. Urban regime theory in comparative perspective. Environment and Planning 12 (1), 195-212.

Sullivan Mort, G.M., Weerawardena. J. Williamson, B., 2007. Branding in the nonprofit context: the case of Surf Life Saving Australia. Australasian Marketing Jounal $15(2), 108-119$.

WIPO World Intellectual Property Organization. 2008. Queensiand Tourist \& Trave Corporation Stands by Their Trade Marks. chttp://www.wipo.int/sme/en/ case_studies/queensland.htm) (accessed 6.05.08.).

Walsh, DC, Rudd, R.E., Moeykens, B.A., Moloney. T.W. 1993. Social marketing for public health. Health Affairs 12 (2), 104-119.

Wiebe, G.D., 1951-1952. Merchandising commodities and citizenship on television. Public Opinion Quarterly 15, 679-691.

Wilson, J.B.. 1979. The Story Experience. London, Scarecrow Press.

Wood, E.H., 2005. Measuring the economic and social impacts of local authority events. International Journal of Public Sector Management 18 (1). 37-53.

Wood, E.H. 2006. Measuring the social impacts of local authority events: a pilot study for a civic pride scale. International Journal of Nomprofit and Voluntary Sector Marketing 11 (3), 165-179.

Woolcock, M., 1998. Social capital and economic development: toward a theoretical synthesis and policy framework. Theory and Society 27 (2), 151-208.

Yin. R. 1994. Case Srudy Research: Design and Methods, second ed. Sage, Thousand Oaks. 